To cite this article: Jean-Thomas Arrighi \& Jean-Michel Lafleur (2017): Where and why can expatriates vote in regional elections? A comparative analysis of regional electoral practices in Europe and North America, Journal of Ethnic and Migration Studies, DOI:10.1080/1369183X.2017.1409164

\title{
Where and why can expatriates vote in regional elections? $A$ comparative analysis of regional electoral practices in Europe and North America
}

\author{
Jean-Thomas Arrighi, NCCR On-The-Move, Université de Neuchâtel, Neuchâtel, Switzerland ; \\ Jean-Michel Lafleur, CEDEM, Université de Liège, Place des Orateurs, Liège, Belgium

\begin{abstract}
DISCLAIMER: THIS IS THE PRE-PRINT VERSION OF THE ARTICLE PUBLISHED IN THE JOURNAL OF ETHNIC AND MIGRATION STUDIES.
\end{abstract}

The final published version can be consulted online at https://doi.org/10.1080/1369183X.2017.1409164

\begin{abstract}
The article constitutes the first systematic attempt to survey and account for the enfranchisement of non-resident citizens in regional elections. Shifting the focus away from the state to the regional demos, it is divided into two parts. First, it examines whether the spectacular horizontal diffusion of external voting legislation widely observed in existing scholarship has also spread vertically to regional elections, through a comparative overview of the conditions of eligibility to the regional franchise in 292 American and European regions. The remarkable diversity of regional electoral arrangements both within and across states calls for a more in-depth explanatory analysis of the 'micro- foundations of diaspora policy' in specific regions. The second part thus compares two negative cases, Flanders and Scotland, where expanding the franchise to expatriates has been seriously considered and yet ultimately failed. It goes on to examine the frustrated outcome in the light of three dimensions of the political opportunity structure: whether the region has the power to alter the composition of the demos (self-determination powers), the expected electoral gains and losses among political parties within the regional party system (electoral interests), and the (in)compatibility of extending the suffrage to expatriates with the pursuit of autonomy goals (self-determination aims).
\end{abstract}

KEYWORDS: Expatriates; voting rights; regions; diasporas; Scotland; Flanders

ACKNOWLEDGEMENTS: The authors wish to thank Rainer Bauböck, Thibaut Jaulin, Philippe Van Parijs, Carlos Closa and the guest editors for their comments on earlier versions of this paper. We are also particularly grateful to Lorenzo Piccoli for asssiting with the data collection and Andreas Perret for generating the maps through $\mathrm{R}$.

FUNDING: This research was supported by National Science Foundation of Belgium (FRS-FNRS) and the National Center of Competence in Research (NCCR) - on the move funded by the Swiss National Science Foundation. 


\section{Introduction}

Recent global surveys found that well over 100 countries have extended the right to vote to their citizens living abroad in national elections (Collyer and Vathi 2007). In spite of its ubiquity and rapid spread across countries on both hemispheres, relatively independently of their migration trajectory and level of economic development, the phenomenon long remained unnoticed in migration studies, at least until the transnational turn shifted the focus away from immigrants to emigrants. In the past 10 years, it has become a subject of social science inquiry in its own right, intensely studied from a variety of disciplines (see Lafleur 2013a for a review of the literature). More recently, considerable attention has been devoted to explaining why an electoral practice that was once seen as democratic anomaly became in a matter of a few decades a new democratic norm, resisted by ever fewer states (Hutcheson and Arrighi 2015). While country-specific variables including dynamics of party competition, emigrant lobbying, or the economic potential of tapping into emigrants' resources, did play a non-negligible role, the most promising research avenues have focused on mechanisms of norm diffusion across states (Lafleur 2015). For instance, Rhodes and Harutyunyan (2010) and Brand (2014) linked the phenomenon to broader democratisation processes while Turcu and Urbatsch (2015) looked at geographic, cultural and linguistic proximity as incentives for states to adopt similar policies. The study of extraterritorial voting has thus emerged as a resolutely inter- disciplinary and predominantly comparative research field, which greatly enhanced our understanding of how states have sought to constitute, embrace and control political diasporas, as well as the reasons underlying their actions (see the introduction by Delano and Mylonas (2017) and the contribution by Gamlen, Cummings, Vaaler 2017).

Yet to date, the scholarship has focused almost exclusively on state elections, thereby neglecting the numerous forms of territorial communities that exist within and across state boundaries. With a few notable exceptions (e.g. Arrighi and Bauböck 2017), it has been indifferent to the level of elections in which non-resident citizens are entitled to vote, thereby providing for a decisive yet partial account of the construction of contemporary cross-border democratic communities and political diasporas. Against this back- ground, the paper aims to introduce the notion of scale in the study of external voting by shifting the focus away from the state to the regional demos, first by conducting a systematic transatlantic survey of regional electoral legislation in this matter, and second by proceeding to an in-depth comparison of two emblematic cases. The article thus responds to the call made in the introduction of the special issue of unpacking the state by looking at how other actors - such as regional governments - drive diaspora policy, and of disaggregating the diaspora, an increasingly popular category of political practice that too often remains treated as a monolithic and taken for granted category of analysis. Given the virtual absence of literature on the topic, our approach is essentially exploratory and our paper may ask more questions than it actually answers. Our main purpose, however, is to offer a more scale sensitive account of the 
transformations of the franchise in a context of interregional and interstate migration, and encourage others to follow suit. To this aim, the article is divided into two parts.

First, we examine whether the spectacular horizontal diffusion of external voting legislation has been limited to national elections, or whether it has also spread vertically to regional elections, through a broad comparative overview of the conditions of eligibility and access to the regional franchise in 292 regions in 17 European states and the three historic federations of North America: Canada, the U.S. and Mexico. Building on an original dataset, the results show that the extension of the franchise to 'regional expatriates' is less widespread than in national elections, an outcome which reflects the resilience of a federal norm, according to which regional citizenship is subordinated to national member- ship, and its scope, bounded within a clearly demarcated territorial jurisdiction. Yet, in the growing number of regions where expatriates may vote, the sheer diversity of electoral arrangements one can find across and within states calls for more in-depth comparative research into the topic, a task we subsequently turn to. The second part moves beyond the descriptive comparative analysis of a large universe of cases in search of an explanation to the persisting disenfranchisement of regional expatriates in two cases where the extension of the franchise has been seriously considered and yet failed to materialise: Flanders and Scotland. Leaving aside diffusionist theories that are essentially ill-suited to account for negative cases, we go on to examine the frustrated outcome in the light of three dimensions of the regional political opportunity structure: whether or not the region has the power to alter the composition of the franchise (self- determination powers), the expected electoral gains and losses among political parties within the sub-state party system (electoral interests), and the (in)compatibility of extending the suffrage to citizens abroad with the pursuit of autonomy goals (self-determination aims). Our findings show that while the former two aspects have influenced the outcome, only the latter has been determinant.

\section{Descriptive comparative analysis: external voting in European and American regions}

\subsection{The regional demos}

The present paper proposes to shift the focus away from the state to the region, an elusive concept that stretches both below and above the state and can be defined politically, cul- turally, economically or in other functional ways (Keating 1998). We are here solely con- cerned with regions as territorial units of government located between the local and state levels that are both representative of and accountable to their own citizens. While suffi- ciently broad to encompass a wide range of cases across and within states, our definition excludes supranational institutions, such as the European or Andean Parliaments, as well as administrative units that do not have a 
democratically elected assembly endowed with autonomous powers. Besides, our understanding of the concept is normatively neutral: it does not seek to capture the difference between a 'nation' and a 'region', a distinction that is essentially contested in multinational federations such as Spain, Canada, or Belgium. Instead, it places the emphasis on the institutional relationship between the state and lower tiers of government that enjoy some degree of political autonomy over a clearly demarcated portion of its territory but falling short of independent statehood. Far from being circumscribed to federations, regional tiers of government can be found in most states, a phenomenon that has been accentuated by decentralisation processes that have spanned democratic states over the past 50 years (Hooghe et al. 2016).

To be sure, these processes have been uneven and led to different outcomes (Keating 2013, 45-46 and 104-111). They have been much more far reaching in relatively large and highly centralised states, such as France or Italy, than in historical federations, such as Austria or the U.S., although in absolute terms, regional governments have remained significantly weaker in the former than in the latter. Size also played an important role, as in smaller states, squeezing in a regional tier of government above the municipal level could hardly be justified. Unsurprisingly, the most radical transformations occurred in those states marked by deep territorial cleavages that were revived and successfully exploited by regionalist or nationalist movements seeking greater territorial autonomy, if not outright independence. Accordingly, what we find are different degrees of internal territorial differentiation ranging from unitary states at the one end of the spectrum to strongly devolved federal states at the other end. In between, there are not only different vertical divisions of powers between central and regional governments, but also different degrees of horizontal asymmetry of powers, with special autonomies for some regions but not others. But despite their differences in terms of policy scope, power or size, regional governments have in common to exercise their power through democratically elected regional assemblies reflecting the significance of the democratic norm that those who are subject to or affected by binding laws should have a say in the making of those laws (Jeffery and Wincott 2010). Regions have thus become spaces of citizenship in their own right, allowing for the emergence of territorially differentiated rights within the same state reflecting the preferences of a distinctly regional demos as expressed in periodic elec- tions (Painter 2002; Piccoli 2016).

Furthermore, migration statistics usually are aggregated at the level of the state, thus obscuring the uneven distribution of stocks and flows throughout regional administrative divisions. While some regions may be primarily concerned with emigration and others with immigration, virtually all are traversed by both phenomena, an empirical fact that radically expands the scope of migration studies beyond the blinders of methodological nationalism (Arrighi 2012, 20-24). In the past decade, a growing body of literature has examined how regional governments had come to play an important role in immigration and immigrant integration policy (see, for example, the edited 
volume by Hepburn and Zapata-Barrero 2014). By contrast, much less attention has been devoted to their bonds and ties to regional emigrant communities, despite evidence that some have actively devised diaspora building policies and institutions commonly portrayed as the exclusive prerogative of sovereign states (Butler et al. 2007). How significant regional variations across and within states in regard to non-resident voting rights are, however, has not been systematically examined.

\subsection{Dataset}

In order to address this question, we built an original dataset measuring the scope of the external franchise in a large universe of cases, based on resources made available by the GLOBALCIT Observatory of the European University Institute, including databases, indicators and country reports on access to electoral rights in Europe and the Americas, and complemented by original data collected on Electoral Commission's websites of individual regions. ${ }^{1}$ To allow for systematic comparative analysis across levels, we excluded all states that have no regional tier of government (e.g. Cyprus, Malta, Luxembourg), those where regional assemblies are not directly elected (e.g. Ireland), but included those where direct elections are held in special autonomy regions only (e.g. Madeira and Azores in Portugal, Aland Islands in Finland). In those remaining countries with multiple layers of elections between the state and municipalities, we selected the level of government with the greatest authority. ${ }^{2}$ In Europe, this results in a sample of 17 states encompassing 194 regions, dis- tributed as follows: Austria (9 Bündeslander); Belgium (3 regions: Région Wallonne, Région Bruxelles-Capitale, Vlaamse Gewest); Croatia (21 Zupanije); Czech Republic (14 Kraje); Denmark (5 Regioner and two autononomous territories: Greenland and the Faroe Islands); Finland (1 special autonomy region: Aland Islands), France (27 regions, including 22 régions metropolitaines and 5 régions d'Outre-Mer), Germany (17 Länder); Hungary (7 Mađarske regije); Greece (13 Peripheries); Italy (18 regions, including 15 regione ordinarie and 3 regione autonome); the Netherlands (4 Landsdelen); Slovakia (4 Zoskupenia krajov) Sweden (8 Riksomraden); Switzerland (26 cantons), the UK (3 devolved assemblies: Scotland, Wales and Northern Ireland) and Spain (17 Comunidades Autono- mas). In addition, we cover 98 regions in the three historical federations of North America: Canada (10 provinces and 3 territories), the U.S. (50 States and 3 unincorporated territories: Guam, Puerto Rico and the Virgin Islands) and the United Mexican States (32 Estados, including Mexico City).

Our dataset falls short of a genuinely global analysis. It nonetheless offers a comprehensive coverage of electoral legislation in all democratically elected regions of the European Union (+Switzerland) and North America and includes cases marked by important variations along a 'symmetry vs asymmetry' horizontal axis and a 'unitary vs. federal' vertical axis. For each of our 20 states and 292 regions, we measured and coded on a six-point scale the degree of inclusion of the franchise in relation to non-resident populations, ranging from maximum exclusion (0) to 
maximum inclusion (1), as laid out in Table 1.

Table 1. Coding rules for measuring the degree of inclusion of the non-resident franchise across state

\begin{tabular}{|l|l|}
\hline 0 & Reserved to residents \\
\hline 0.2 & Limited to civil servants and/or military personnel posted abroad \\
\hline 0.4 & In-country voting only \\
\hline 0.6 & Subject to a maximum period of residence abroad ( $<$ or $=$ to fifteen years) \\
\hline 0.8 & Limited to first generation emigrants \\
\hline 1 & All citizens abroad (including emigrants' descendants / citizens born abroad) \\
\hline
\end{tabular}

The results are summarised in Figures 1 and 2 (for Europe) and 3 and 4 (for North America), which highlight the contrast between national and regional legislations in the great majority of our cases. ${ }^{3}$ The entire dataset can be consulted in the appendix (see Supplemental data).

\subsection{Interregional migration}

Before examining the franchise of non-residents, an important preliminary step is to define the default category of voters in regional elections. Unlike states, regions generally do not have the power to 'make' their own citizens through citizenship laws defining the conditions of acquisition and loss of membership status (Tilly 1997). Instead, the right to vote in regional elections is derived from state nationality, and activated through residence in the regional jurisdiction, according to a clear hierarchy of legal norms (Jackson 2001). The automatic enfranchisement of all state nationals who are also resident in the region is a near universal norm that stems from a twofold democratic requirement of non-discrimination among citizens and free mobility within the state. While largely unchallenged nowadays, this aspect of the regional franchise has been fiercely contested in the past. In federations that 'came together' (Stepan 1999), it is the product of a long historical process described by T. H Marshall as a 'geographic fusion' - in the course of which regional governments fought to retain what they portrayed as their age-old right to deter- mine who should be regarded as a member and entitled to vote in their own elections. In the U.S., the principle was adopted in 1874, soon after the civil war, when the federal government sought to force Southern states to confer U.S. citizenship and grant the right to vote to former slaves through the 14th and 15th Amendment, respectively (Kousser 1999). But discriminatory practices persisted at least until a decisive judgment of the Supreme Court in 1972. ${ }^{4}$ Similarly, in Switzerland, the first federal constitution of 1848 entrenched the right of (Christian) Swiss citizens to take up residence in a canton other than their 'place of origin', a disposition that generated a great deal of anxiety among urban cantons that feared a mass influx of 'Confederates' from their rural and poorer neighbours. The initial Constitution addressed their concerns, by allowing cantons to restrict the local suffrage 
to their own citizens and subject the right to vote of citizens of other cantons in cantonal elections to a two-year minimum residence requirement, a period that was brought down to three months as part of the 1874 constitutional overhaul (Studer, Arlettaz, and Argast Kury 2013).

In our sample, the only two cases of discrimination against co-nationals can be found in the arguably peculiar Finnish special autonomy region of Aland Islands and the Italian region of Trentino-Alto Adige/Südtyrol. In the former case, Finish citizens from the main- land acquire the right to vote and to own property on the island after five years of residence, a compromise that was meant to ensure the cultural preservation of a Swedish-speaking and numerically small autochthonous population (Murray 2012, 131-137). In a similar vein, the right to vote in TrentinoAlto Adige is restricted to Italian citizens with at least four years of residence in either of the two provinces. ${ }^{5}$ Rather than an exception to the rule, this highly idiosyncratic provision was introduced with the aim of mitigating the impact of immigration on the consociational arrangement between the Italian and German-speaking communities, whose democratic representation depend on their relative demographic weight in each province. The case thus exhibits elements of non-territorial autonomy, which cast it aside from federal or regional arrangements that are essentially territorial (Elazar 1985). By extension, interregional migrants automatically lose the franchise in their region of origin as they acquire it upon taking up residence in another region, a rule that applies to virtually every observation in our sample. ${ }^{6}$ The only case where an extension of the franchise to former residents who have emigrated to another part of the state was seriously considered is the Basque Country, where in 2011 the regional branch of the Popular Party then in power in the central government put forward a proposal aimed at enfranchising all those individuals who were forced to leave the Basque Country because of a direct threat or pressure from ETA. ${ }^{7}$ The symbolically charged bill was met with strong opposition in the Basque Parliament, where the Basque Nationalist Party (PNV) deemed it as 'absurd', while the Socialist Party (PSOE) pointed to the practical impossibility of separating former residents who left the Basque Country as a direct consequence of ETA-sponsored terrorism from those who emigrated for other purposes. ${ }^{8}$ In the absence of a cross-party consensus, the plan was ultimately abandoned in 2011, the legislator thus reasserting the principle of territoriality over that of personality as the corner- stone of political representation in the Spanish State of Autonomies.

To sum up our empirical analysis thus far, the regional demos is made of nationals of the state who are also resident in the region, thereby excluding former residents who emigrated to another region within the same state. This aspect of the regional franchise may seem rather trivial. However, it marks a crucial difference between regions and states resulting from their distinctive external environment. While formally emigrants - that is individuals leaving the territorial jurisdiction of the region - citizens relocating to another region do not qualify as expatriates. It is only once they trespass the international frontier of the state that they can be considered as such, and therefore fall 
into the administrative category of citizens abroad or non-resident citizens, a group of potential voters to which we now turn.

\subsection{Interstate migration}

As far as our European cohort is concerned, the data shows that the overwhelming majority of states in our sample have extended the franchise to their citizens abroad in national elections. Out of 17 states put under scrutiny, only Greece has no legislation enabling its expatriates to cast a ballot from abroad, while Denmark, the UK, Germany ${ }^{9}$ and Sweden still make it conditional upon past residence in the country or a maximum period of time spent abroad (Hutcheson and Arrighi 2015). In all other states, voting from abroad has become a general right of all nationals, irrespective of how they acquired their nationality and whether or not they ever resided in the country (Figures 1 and 2).

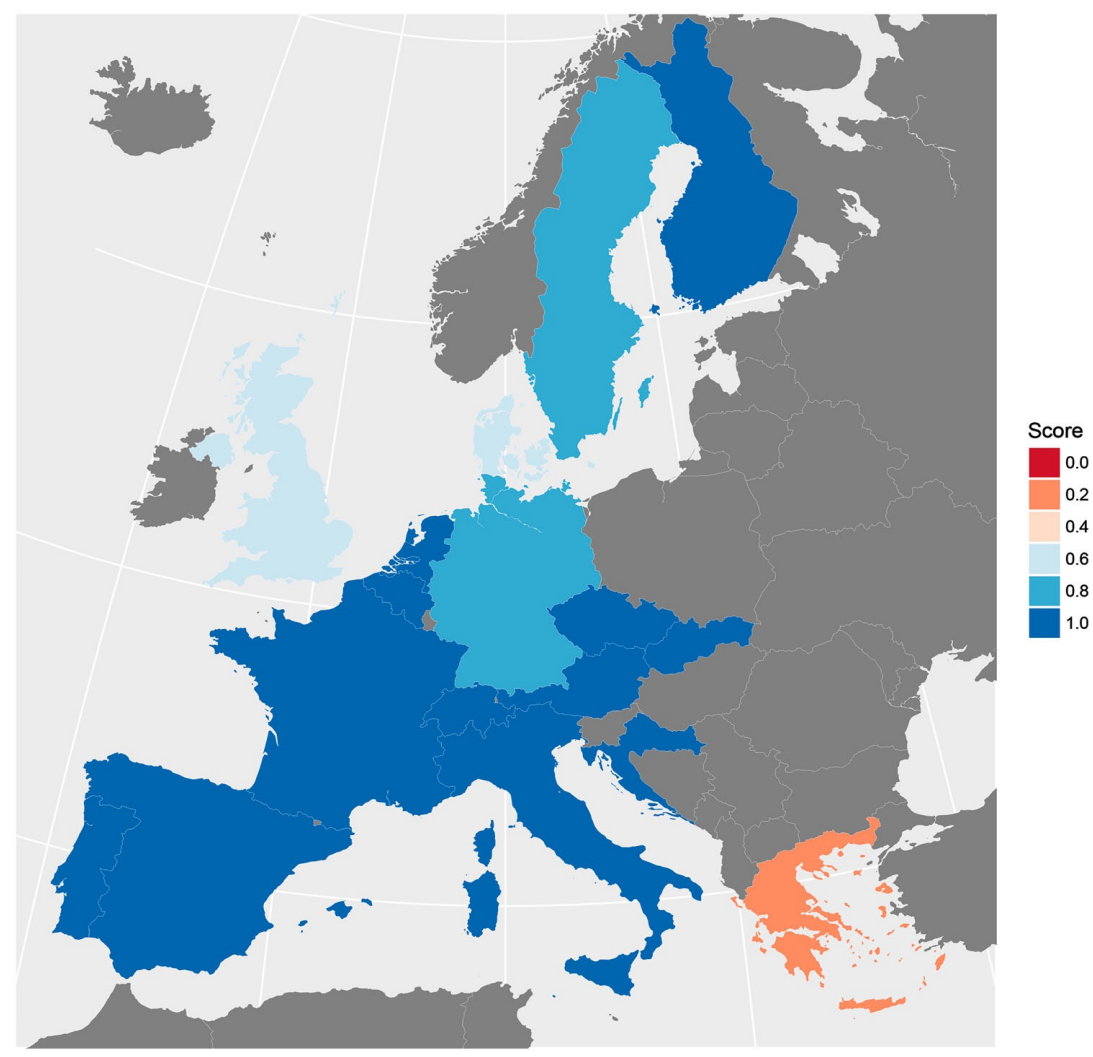

Figure 1. Voting rights of non-resident citizens in Europe: national elections.

When zooming into the regional level, the picture becomes quite different. Overall, the franchise clearly is less inclusive, though restrictions come in different shades and show significant intrastate variations, mainly concentrated in the old central European federations of Austria and Switzerland and spilling across the linguistic border to the Italian province of Trentino-Alto Adige. In Austria, the three provinces of Lower Austria, Tyrol and Vorarlberg have extended the right to 
vote to those whose principal domicile was in the province immediately before emigration and have resided abroad for a maximum period of 10 years. In Switzerland, where cantonal citizenship is a constitutionally recognised status and naturalisation powers are exercised concurrently by the federal state, cantons and municipalities (Achermann et al. 2015), expatriates can cast a ballot from abroad in some cantons but not in others. Our analysis must therefore fully acknowledge the difference between states where electoral matters are an exclusive competence of the central government, and those where regional governments enjoy some legislative room for manoeuvre to determine the composition of their own demos. The former does not necessarily translate into an exclusive franchise, but merely implies that a single electoral law applies indiscriminately throughout all regions. At one end of the spectrum, Denmark or Greece show an equally exclusive franchise across levels - disenfranchising emigrants after two years abroad or allowing residents to return on Election Day, respectively. Conversely, Spain exhibits an equally inclusive franchise across state and autonomous elections. Since the democratic transition, 'absent residents' [sic] have been able to mail their ballot from abroad in the elections of the autonomous community where they last resided before emigrating, or in the event that they were born abroad, in their 'region of ascription' (adscripción), that is the Autonomous Community of residence of one of their ascendants. In between, we find all sorts of idiosyncratic arrangements such as in French regions, where expatriates can choose to register in any municipality where they can justify some remote family ties, but must return or appoint a proxy there to cast a ballot on Election Day.

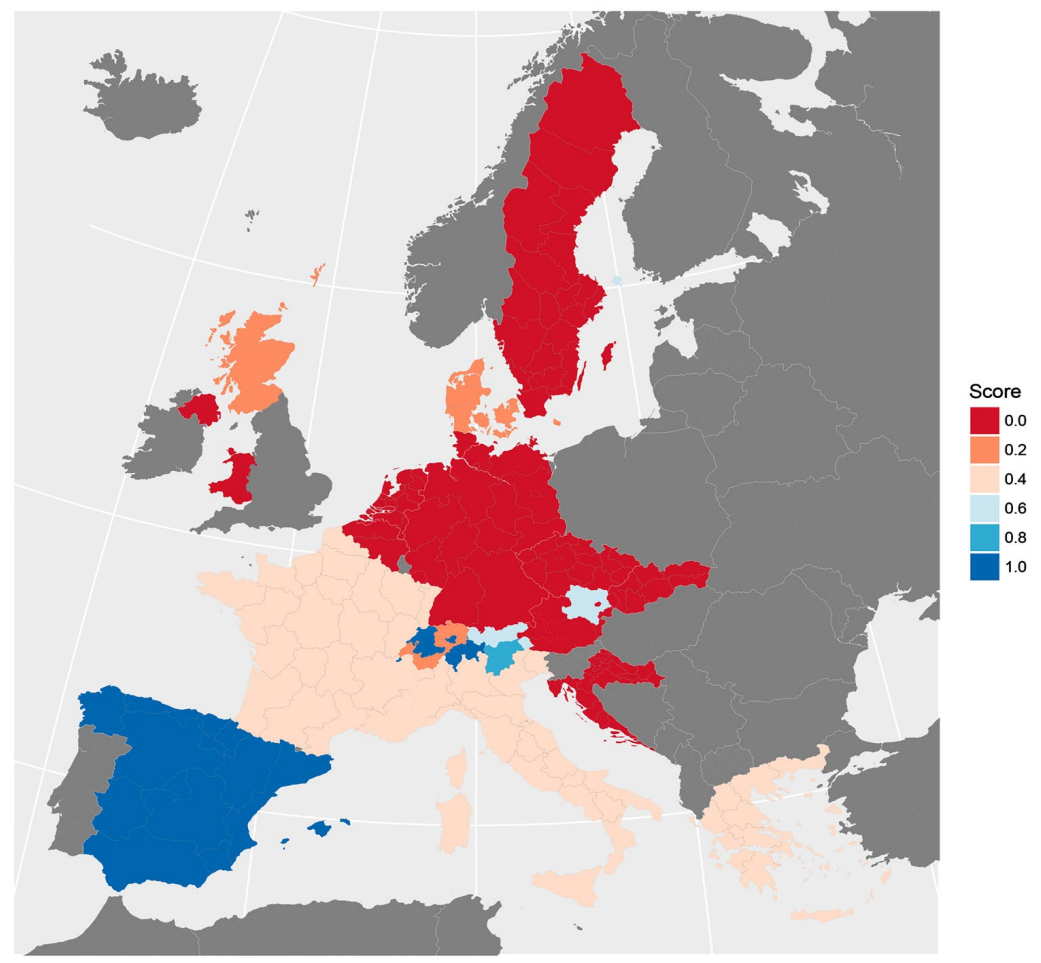

Figure 2. Voting rights of non-resident citizens in Europe: regional elections. 
Our results suggest that a partial devolution of self-determination powers encourages some regions to act as laboratories of policy experiments and others to imitate the 'best practices' of their neighbours, a well-known phenomenon among scholars (and advocates) of federalism. It does not follow, however, that regional governments who have the power to reach out to their co-regionals abroad necessarily do so. In fact, and somewhat counter- intuitively, among those regions that enjoy this prerogative, few actually made use of it. The case of Italy, where only citizens of the autonomous region of Trentino-Alto Adige may cast a ballot from abroad despite a 1999 Constitutional reform allowing all Italian regions to design their own electoral system is illustrative in this respect (Grosso 2012). ${ }^{10}$ In a similar vein, the self-governed islands of Azores and Madeira in Portugal consistently refused to grant the right to vote to their sizeable populations abroad, notwithstanding a powerful and well-organised emigrant lobby calling for a reform.

Across the Atlantic, the three historic federations of Canada, the U.S. and Mexico show a messier picture, mainly because regional governments enjoy far more self-determination powers in electoral matters. In Canada, the persistence of a comparatively restrictive franchise in federal elections, excluding emigrants who have spent more than five years abroad, makes the case somewhat less instructive. In the U.S., all states let former residents abroad vote in elections there, as long as they have retained U.S. citizenship, but 24 states have extended the franchise to secondgeneration emigrants, that is, U.S. citizens born abroad who can vote at the 'voting residence' of one of their parents (Jones-Correa and Wong 2015). The American case points to the significance of the broader electoral set up and the implications of the extension of the national suffrage for substate elections: in 1976, the decision of the federal government to enfranchise non-resident citizens in federal elections forced all states to reform their legislation in order to let their own citizens abroad elect the Members of the Electoral College (who in turn elect the President), Members of the Senate (where each state returns two seats) and Members of Congress (who run in one of 435 electoral constituencies). Though states were not by law obliged to provide for out-of- country voting in gubernatorial elections, virtually all of them replicated the federal electoral arrangement to their own regional executive and legislative assembly. Hence, the extension of the regional demos was rather an indirect consequence of the necessity to implement a federal legislation than a bottom-up request of regional governments (Figures 3 and 4). 


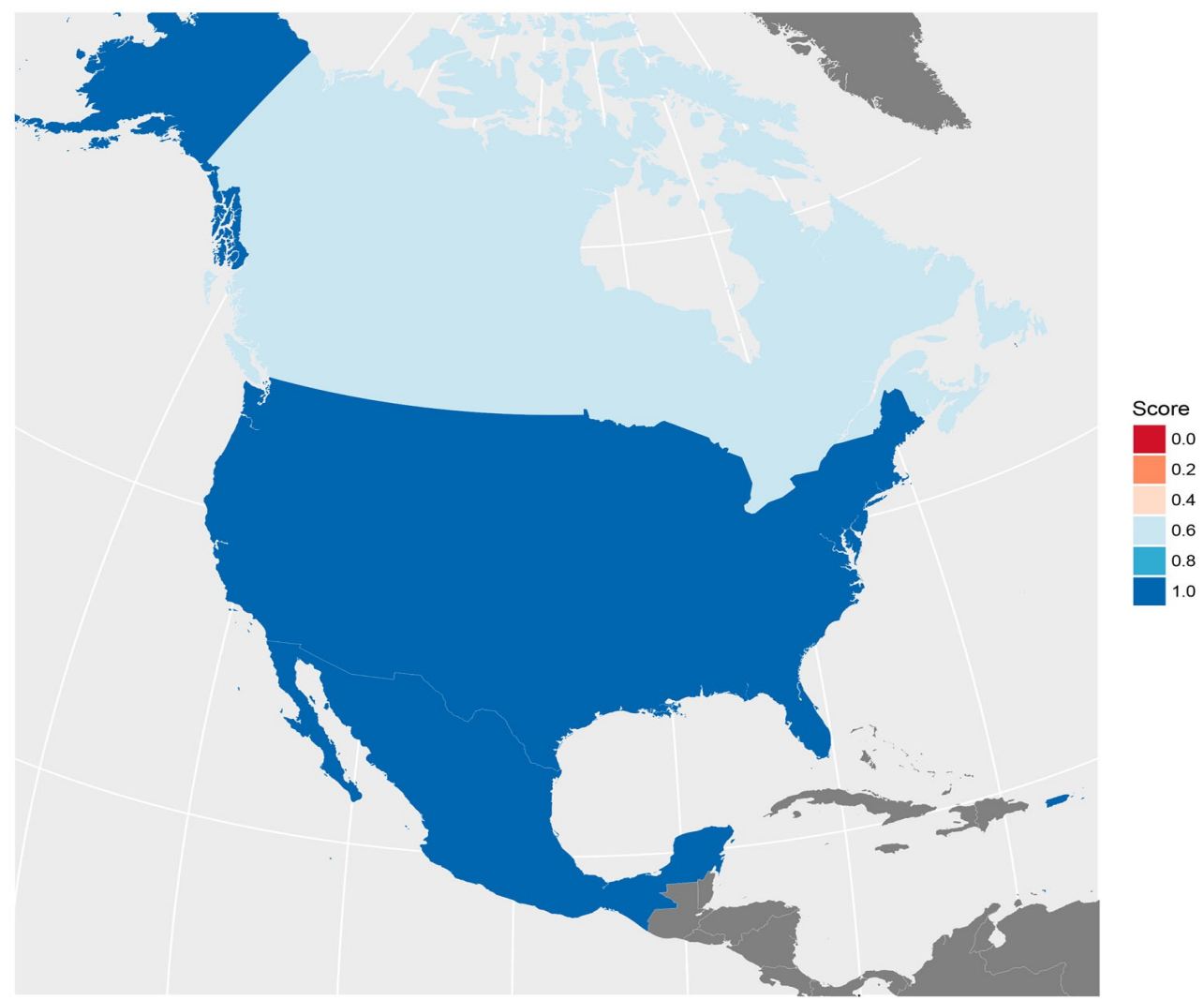

Figure 3. Voting rights of non-resident citizens in North America: national elections.

A more puzzling case is Mexico, where several states have recently passed legislation extending the right to vote to their 'ciudadanos emigrados'. This trend can only be under- stood in the light of the radical transformation of the concept and practice of external citizenship in Mexico over the past 20 years. In 1998, it turned away from its long-standing policy of disregarding its sizeable communities of emigrants settled in the U.S. by opening the gate to dual citizenship. A few years later, Mexican citizens abroad were formally granted the right to participate in presidential elections, although few were able to navigate the extremely cumbersome electoral registration procedure to cast a ballot in 2006 (Lafleur and Calderon Chelius 2011). However, this attempt to mitigate the electoral impact of a large and unpredictable electorate was short lived and the past few years have seen several reforms aiming at facilitating access to the ballot to boost participation rates (Pedroza 2015). Besides, the scale of the policy has also been gradually broadened. Initially limited to presidential elections, the right to vote from abroad was extended to the elec- tions of senators and gradually spilled over to lower tiers of government, as states made use of their wide legislative power on electoral matters. To this date, 11 states have passed legislation enabling their citizens abroad to vote for the elections of the state Execu- tive. In Chiapas and Zacatecas, the legislator went a step further by introducing a reserved seat for a 'diputado migrante' directly elected by the external electorate in their respective Parliaments. Whether or not this represents an attractive precedent soon to be emulated by other sub-state governments is unclear, though there is 
some evidence that the cons of the reform may outweigh the benefits: In 2014, the state of Michoacán abandoned a similar disposition, after the cost of bringing the ballot to Michoacanos abroad proved too high and their participation, too low (Pedroza 2015).

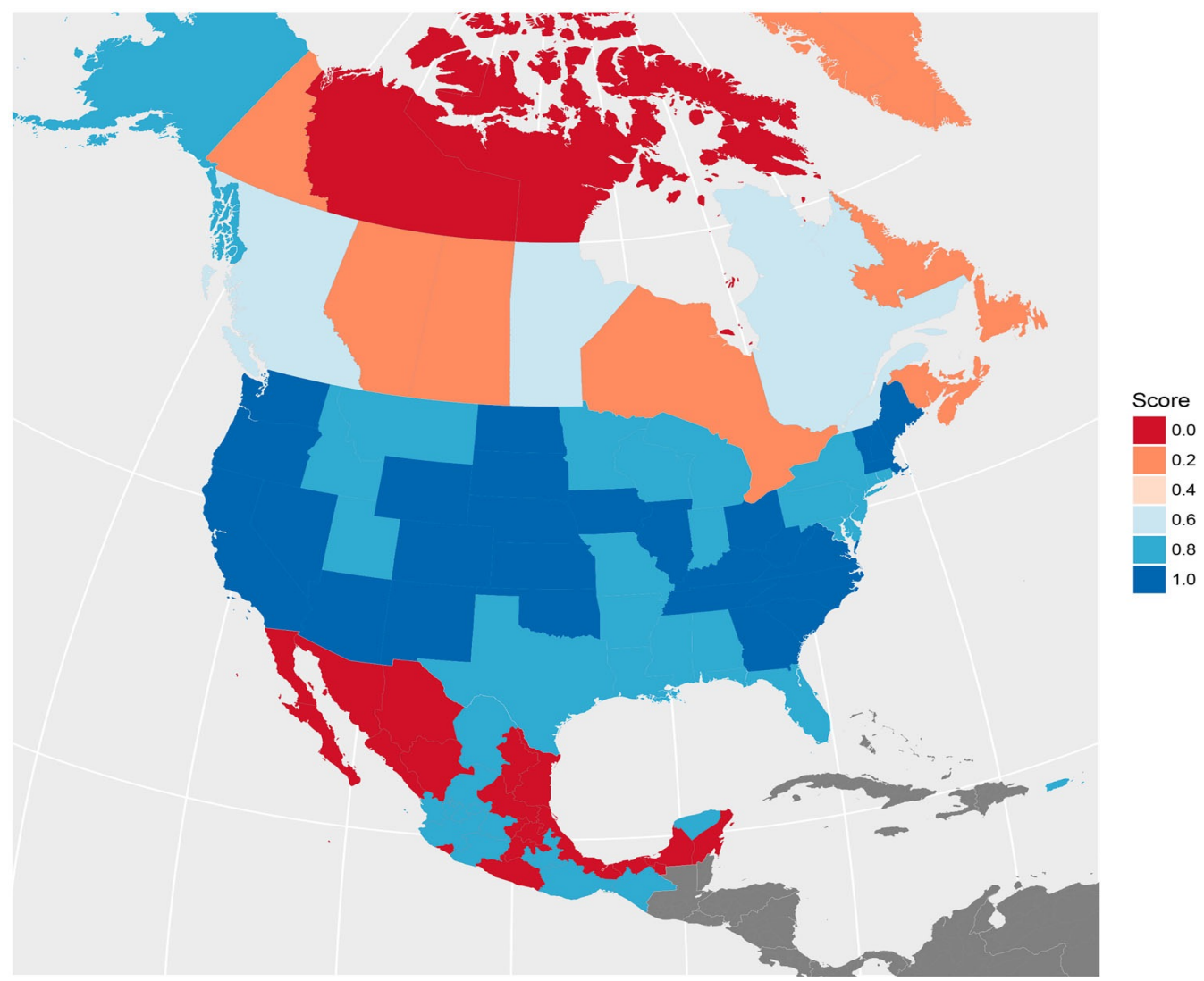

Figure 4. Voting rights of non-resident citizens in North America: regional elections.

Our comparative overview shows that the remarkably rapid horizontal diffusion of extraterritorial voting legislation in state elections only partially spread vertically, to regional elections. Rather than a diffusion failure, this outcome reflects the resilience of a federal norm, according to which regional citizenship is subordinated to national membership, and its scope, bounded within a clearly demarcated territorial jurisdiction. While this norm has remained hegemonic in relation to interregional emigrants - who automatically lose the franchise in their region of origin when taking up residence in another region of the same state in virtually all cases in our sample, the same cannot be said of interstate emigrants, who may cast a ballot from abroad in a growing number of regional elections. The sheer diversity of electoral arrangements one can find across and within states and the certainty that each region has its own story to tell call for a smaller and more in-depth comparative inquiry, a task we turn to in. 


\section{Explanatory analysis: Scotland and Catalonia compared}

The second part of this essay proposes to examine and compare the debate surrounding the (dis)enfranchisement of emigrants in Scotland and Flanders. In both instances, the extension of the regional franchise to non-resident citizens has been seriously considered and yet failed to materialize. The originality of our approach lies in the selection of negative cases according to the 'principle of possibility' - i.e. where the outcome of interest was possible even though it did not occur - a methodological choice that remains unusual despite its significant potential for theorytesting (Mahoney and Goertz 2004). Selecting two cases that share a similar outcome but differ markedly along relevant structural aspects allows us to infer causality, a widespread approach to small-n comparative case study following the principles of a co-variational analysis (Blatter and Haverland 2012, 5). The cases build upon extensive periods of fieldwork conducted over the years by the authors and a wide range of primary data including parliamentary transcripts, press articles, stakeholder interviews and regional legislation.

Without entering the vexed question of whether or not Scotland and Flanders objectively qualify as 'nations' - as opposed to mere 'regions' - we start from the observation that they both constitute prominent examples of sub-state nationalism, which led to a pro- found restructuring of their respective states over the past decades. In a nationalist context, the exercise of the franchise constitutes the ultimate expression of the people's right to self- determination and its scope delineates the community of citizens. Hence, the struggle over its contours is an inherent aspect of sub-nationalist mobilisation as well as a privileged site to explore the dynamics of competitive nation-building between political parties and governments operating in the state-wide and regional arena. We do not contend that our findings can be readily applied or generalised to other regional governments, and we are fully aware that our focus introduces a crucial variable that is absent in most 'regions', where sub-state elites do not challenge the territorial integrity of the state in which they are incorporated. In such cases, the failure of a vertical diffusion of the external franchise may primarily stem from the mutual indifference between political parties competing for seats in 'second-order elections' and former residents who neither identify with nor manifest interest in the politics of their region of origin (Schakel and Jeffery 2013). Nevertheless, our explanatory framework places the emphasis on three dimensions of the domestic political opportunity structure, two of which potentially apply to all regional government whereas the third one focuses more narrowly on the 'nationalist' quality of our cases.

The political opportunity structure stresses the dimensions of the political environment that provide actors with incentives and constraints for action (Kriesi 1995). We hypoth- esise that whether or not the regional demos is extended to non-residents depends on the relative openness of three conceptually distinct yet empirically related aspects of the regional environment: whether or not the region has the power to alter the composition of the franchise (self-determination powers), the 
expected electoral gains and losses among political parties within the sub-state party system (electoral interests), and the per- ceived compatibility of an extension of the suffrage to citizens abroad with the pursuit of autonomy goals (self-determination aims). We successively examine the reasons that led to the persisting exclusion of emigrants in Scotland and Flanders and conclude with a comparative discussion on the cases and the lessons that can be drawn from them.

\subsection{Flanders: from 'Belgians' to 'Flemings' abroad}

The right of Belgian citizens to cast a ballot from abroad is relatively recent and limited to national legislative elections (since 2002) and European elections (since 1994). Their dis- enfranchisement in regional elections does not mean, however, that Flemish political elites have shown no interest in cultivating ties with Flemish populations residing abroad or in the enclaved region of Brussels, nor that the question of their enfranchisement is disconnected from the ongoing ethnolinguistic conflict between Flemings and Francophones. On the contrary, the fear of a potential francophone interference in Flemish politics has long defined the debates on external voting in Belgium, and impeded upon the extension of the regional demos to 'Belgian' citizens abroad. To date, the regional demos has been reserved to Belgian citizens residing in Flanders and, since 2011, partially extended to Belgian citizens residing in Brussels and voting for Flemish-speaking party lists there. Moreover, recent institutional and electoral changes may soon turn the Flemish case from a dog that refused to bark to a highly peculiar one where both Flemings residing in other parts of the Belgian state and abroad may be able to participate in regional elections.

For several decades, Flemish regional authorities have actively sought to build connections with citizens outside the country, offering services ranging from language classes and summer camps for children to managing programmes aimed at facilitating their return to the homeland (Lafleur 2013b). Such efforts to reach out to expatriates, however, contrasts sharply with Flemish nationalists' ambivalent if not predominantly hostile attitude to immigrants, at least since the first electoral breakthrough of the radical right nationalist party Vlaams Blok in 1988 and subsequent rise of the socially conservative Nieuw-Vlaamse Alliantie (N-VA) (Pauwels 2011). The tension between immigrant and emigrant rights lies at the core of electoral debates in Belgium. Indeed, the first legislation on external voting, adopted in 1998, was in fact a compromise between the preferences of governing parties (made of Socialist and Christian Democrats rather inclined to enfranchise immigrants) and opposition parties (chiefly the Liberals, who expected to gain new voters among emigrants). The constitutional reform that was eventually passed gave the right to vote to EU citizens in municipal elections in exchange for the adoption of a legislation enfranchising Belgian expatriates in national elections. However, the latter legislation proved so complex that only 18 expatriates managed to navigate an extremely cumbersome registration procedure to cast a vote in the 1999 legislative elections. 
Access to the ballot of Belgians abroad was considerably facilitated in 2002, as part of a profound revision of the legislation sponsored by the new governing coalition between the Socialist and Liberal parties. Two Flemish-speaking parties - Vlaams Belang and the Christian Democratic Party (later relabelled CD\&V) - expressed strong reservations against the possible influence of Frenchspeaking expatriate voters in Flemish constituencies. Indeed, a central feature of the 2002 legislation was the freedom left to expatriates to register in any electoral district in Belgium, irrespective of past residence or 'genuine ties' requirements other than holding Belgian citizenship. As some news reports suggested that a small number of expatriates used French-speaking registration forms to register as voters within a Flemish municipality, some Flemish MPs militated against the extension of the suffrage to Belgian citizens abroad on ethnolinguistic grounds. For Daniel Van Poucke (CD\&V), '[T] he right to vote [of expatriates] will mainly create new Frenchspeaking voters. Obviously, this is interesting [for Francophone parties] in the Brussels-HalVilvorde electoral district because French-speaking and Flemish parties compete with each other there. ${ }^{11}$

Under these circumstances, granting regional voting rights to 'Belgian' (as opposed to 'Flemish') citizens abroad was considered by the dominant Flemish parties as incompatible with a nationbuilding project striving to insulate the Brussels periphery from a francophone interference. Henceforth, replicating the national legislation in regional elections was not seriously considered. Instead, the extension of external voting rights at the regional level initially took a different - and unusual - route by creating 'Flemish expatriates within Belgium': Following the 2001 inter-party agreement (the so-called Lombard Accord) that profoundly reshaped the institutions of the Brussels Region, Flemish voters residing in Brussels - who represent a small minority of the electorate in this region - may cast two ballots in regional elections: one to elect their representatives in the Brussels Parliament and another, in the Flemish Parliament. The latter has far-reaching powers in matters affecting the entire Flemish-speaking community, chiefly in cultural matters, including education policy. The purpose of the reform was thus to enhance its democratic legitimacy towards what amounts to a kin-minority residing in Brussels. As a consequence, and albeit in a distorted version, the new framework has created a peculiar type of 'regional expatriates' allowed to participate in elections in another region of the same state, a highly idiosyncratic if not unique provision that does not exist in any other federation in our sample, as shown in the first part of the paper.

After 2001, successive legislative bills proposing to extend the right to vote to Belgians abroad in regional elections proved unsuccessful. However, the opportunity structure changed with the victory of a new governing coalition at the Federal level in 2014. Under the leadership of the Flemish nationalist party N-VA, the government committed itself to extending the franchise to Belgians abroad in regional elections, with the implicit aim of distinguishing it from the local 
demos while putting it on a par with the national one. The nationalist underpinnings of such proposal are well encapsulated in the words of a Flemish N-VA MP, who claimed that '[w]e must put an end to this unfair treatment since, according to our Constitution, regional and federal authorities are on an equal footing'. ${ }^{12}$ This U-turn must be understood against the background of a concomitant reform of the electoral law putting an end to expatriates' freedom to choose their munici- pality of registration in federal elections. As a result of a legislative change vocally promoted by Flemish parties, non-resident voters now must justify biographical ties in a specific electoral district in order to be able to register there. The reform represents a major shift in the relation between Belgium and its expatriates: In the new electoral context, 'Belgian' expatriates have been replaced instead by 'Flemish', 'Walloon' and 'Brussels' expatriates, each tied to a geographically discrete region.

Belgian expatriates have ceased to exist as a generic administrative category - at least for electoral purposes - and so did the (largely inflated) risk of Francophone expatriates casting a vote and therefore influencing electoral outcomes in the Flemish region. As a result, Flemish nationalists of N-VA now actively support the adoption of a federal legislation on an external franchise in regional elections. In August 2015, ${ }^{13}$ the N-VA-affiliated President of the Flemish Region Geert Bourgeois got personally involved, by making use of his right to call for a conciliation committee between Regions and the Federal authority in order to reach a compromise on this matter. Shortly after, the Federal Interior Minister Jan Jambon (also N-VA) submitted a bill based on the observation that 'there is no reason why Flemings living abroad should be allowed to vote in federal elections, but not in regional ones'. ${ }^{14}$ At the time of writing, the current government's legislative proposal is set to be discussed in Parliament in 2017. Its fate will be subjected to the approval of a $2 / 3$ majority of the Federal Parliament combined with a single majority in the Flemish and Franco- phone parliamentary groups. Despite the high institutional thresholds inherent to the Belgian consociational system, its adoption appears very likely for all parties but the Francophone Socialist party have come to support it.

\subsection{Scotland: a nation of residents?}

With an estimated two million people who left Scotland in the nineteenth century and as many who did so in the twentieth century, Scotland has long been a country of protracted emigration (McCrone 2002, 101). Besides, the outflow continued well into the 1990s, so that by 2011, there were still over 800,000 Scots-bon emigrants residing in other parts the UK, and another 200,000 abroad, the first generation alone representing over $20 \%$ of the domestic population (Scottish Government Research 2009a). As such, their enfranchisement bore the potential of profoundly affecting electoral outcomes in a country of just over 5 million. In the absence of a democratically elected parliament in Edinburgh until 2001, the issue of who ought to be included in and excluded from the franchise in Scottish elections came relatively late. By adding a democratic tier to 
administrative devolution (Mitchell 2006), the Scotland Act 1998 raised the need to define the boundaries of the Scottish demos, an issue extensively debated in the House of Commons in June 1997. Ultimately, the decision was made to use the registry of local government electors for both the referendum on devolution and subsequent elections for membership of the Scottish Parliament. The consequences were twofold.

First, in accordance with the federal norm that all citizens of the state should be auto- matically granted the right to vote in regional elections when taking up residence there, British (and Commonwealth) citizens ${ }^{15}$ born in other parts of the United Kingdom were automatically enfranchised. But the use of the local registry went a step further: On the one hand, EU citizens residing in Scotland, who under the provisions of the 1992 Maastricht Treaty are entitled to vote in municipal elections in any Member State, were also enfranchised, and therefore given the opportunity to have their say in the 'settled will of the Scottish people'. On the other hand, British citizens born in Scotland and residing elsewhere in the United Kingdom or abroad were deliberately excluded from the initial composition of the Scottish demos. The decision to make residence in Scotland both a sufficient and necessary condition to the franchise considerably strengthened the national movements' liberal credentials, by giving England-born British nationals, Commonwealth and EU citizens the opportunity to become 'political Scots', but denying it to those whose membership claim was exclusively based on a shared Scottish ethnicity or ancestry (Kiely, Bechhofer, and McCrone 2005). While the proposal was eventually adopted, the 1997 parliamentary debates reflect the absence of a cross-party consensus and shed light on distinct conceptions of the Scottish demos among the main parties. For a conservative MP, the bill meant not less than the 'government intending to give a Greek waiter temporarily working in a backstreet café in Edinburgh the right to vote in an election about Scotland's future, but denying it to a Scottish journalist working here in Westminster for The Scotsman'. ${ }^{16}$ By contrast, a Labour PM could hardly conceal his resentment towards emigrants 'who have made their choice to leave Scotland to seek fame and fortune elsewhere ... If that is their decision, one of the penalties they have to pay is that they cannot vote in elections in Scotland ${ }^{17}$ Speaking on behalf of the Scottish National Party, Alex Salmond's intervention encapsulates the party's ambition to downplay the ethnic undertones of Scottish nationalism: "Is [the Hon. Gentleman] incapable of understanding why, as leader of the Scottish National Party, I am perfectly comfortable with the idea of people from England, Wales, France, the rest of Europe, or Timbuktu, who are resident in Scotland and contribute to the community there, voting on the future of the country?"18

The debate over the boundaries of the franchise regained prominence in the run-up to the 2014 independence referendum. While the initial determination of the demos on the eve of the devolution referendum had remained largely unnoticed, the issue gained con- siderable salience in the context of the independence referendum, for at least three reasons. First, successive Scottish governments 
have fully embraced the global trend of strengthen- ing the ties with their communities abroad in order to tap into their economic resources (Arrighi 2012, 240-250, Scottish Government Social Research 2009b). Second, the stakes of the referendum were considerably higher: eligible voters were no longer invited to elect the composition of a devolved parliament while ultimate sovereignty lies in Westminster, but to cast a ballot in a referendum that may lead to the disintegration of a 300year union with England and the creation of a new sovereign state. Last but not least, Scottish emigrants could rightly claim to be potentially severely affected by the outcome of the referendum, especially because their citizenship status would change in the advent of a yes vote, the SNP government's draft Constitution proposing that all persons born in Scotland would automatically be granted Scottish citizenship.

Nevertheless, the SNP government clung to its vision of a Scottish demos based on residence, not ethnicity, arguing that 'the international community might question the legitimacy of a referendum if the franchise is not territorial'. The persisting exclusion of non- residents thus must be understood as a strategic move of the SNP, whose primary concern was to project Scotland internationally as a 'responsible nation' with a 'fair and inclusive national identity' (Scottish Government 2015), whose claim for independence is not rooted in a parochial ethnicity but is the expression of a culturally plural and diverse resident population.

\subsection{Comparative analysis: political opportunity structure and enfranchisement}

Our examination of the debates surrounding the composition of the regional demos in two prominent cases of nationalist mobilisation is illustrative of how democratic boundaries can be internally contested in a context of 'inter-national' mobility, both within and outside the state. In Scotland as well as in Flanders, whether or not emigrants ought to be entitled to vote in regional elections has not been pressed on the top of their respective agendas. Yet, the question did arise in several occasions, as a collateral consequence of ongoing processes of competitive nation-building, whereby political elites and governments at multiple levels compete for the hearts of the same people (Norman 2006). While mainly fought within the state, the conflict over the definition of the 'people' has spilled over to British and Belgian citizens abroad. Under the leadership of nationalist parties committed to achieve independent statehood, the Flemish regional government and Scottish administration have engaged in ambitious diaspora building projects through policies and institutions directed to what they framed as their own diasporic com- munities. Yet, in both instances, the economic and cultural integration of populations residing outside their territorial jurisdiction has not been accompanied by their political incorporation through an extension of the franchise. While nationalists in both cases have resisted calls to lift residence restrictions, they have done so for different reasons. We now examine and contrast our findings in the light of the three aspects of the political opportunity structure mentioned earlier. 
Self-determination powers: Unlike states, we saw that regional governments have limited control over the content and scope of electoral legislation. In Flanders, the long-standing opposition of several political parties to the enfranchisement of Belgians abroad mainly stemmed from the registration procedure of the national franchise, which allowed non-residents to choose their municipality of registration. The twin effect of a state-wide electoral reform that put an end to this liberty combined with institutional reform of the Brussels region that split the electoral district of Bruxelles-Hal-Vilvorde along linguistic lines are thus key to understand Flemish nationalists' recent conversion to extending the suffrage to (Flemish) citizens abroad in regional election. By contrast, institutional barriers have been much lower in Scotland, where the 1997 referendum on devolution and the 2014 referendum on independence provided Scottish elites with two windows of opportunity to change the legislation and shape the Scottish demos according to their own preferences with limited involvement from the British state.

Electoral interests: The second dimension of the political opportunity structure focuses on the expected electoral impact of the reform, with some parties envisaging gains and others, losses. In Scot- land, the SNP has repeatedly been accused of manipulating the composition of the demos for mere electoral calculations, Scottish expatriates being portrayed as more 'unionist' than their domestic counterparts. As the external franchise for British elections is itself comparatively restrictive - combining a 15-year restriction on the length of residence abroad with a highly cumbersome registration procedure - the electoral behaviour of British expatriates is largely unknown. However, in regard to the enfranchisement of a fraction of the electorate whose partisan behaviour is essentially unknown prior to the reform, electoral (mis)perceptions and speculations do matter a great deal and David Cameron's recent pledge to lift the 15-year cap gives an indication of the expected impact of the reform on the domestic vote - widely perceived as benefiting the Tories and pro-Union parties. In Flanders, we saw that nationalist parties did not initially consider Belgian citizens abroad as a promising electoral reservoir or privileged electoral clientele. Yet, these fears progressively vanished as the experience of external voting at the national level consistently showed that N-VA enjoyed similar levels of electoral support at home and abroad.

Self-determination aims: Our final and determinant dimension of the opportunity structure concerns the relative compatibility of the external franchise with what we suggest to call selfdetermination aims, that is the pursuit of autonomy goals that is the defining feature of sub-state nationalist parties. It constitutes the main difference between the Scottish and Flemish case, as well as the most important reason for the former's selective inclusion of immigrants over emigrants, and the latter's long-standing hostility to both. On the one hand, the territorial boundaries of Scotland - notwithstanding the controversy over the delimitation of territorial waters encompassing both North Sea Oil and British military interests - have been largely unchallenged. In the absence of a sizeable internal minority vehemently opposed to independence, the left-leaning Scottish 
National party has used the franchise as a means to fulfil the strategic aim of enhancing the legitimacy of the nationalist cause, in an international environment that leaves no room for outright ethnic claims. As for Flanders, the immigrant and emigrant franchise have also been debated simultaneously, although the reluctance of nationalists to extend the suffrage to either category mainly resulted from the Flemish movement's long-standing concern with the establishment of a linguistically homogenous and contiguous territorial jurisdiction. In regard to emigrants, however, their attitude changed as soon as they were offered guarantees that all Belgians in Brussels or abroad who could speak Flemish, but only such Belgians, could vote.

Notwithstanding the explanatory power of institutional constraints and expected electoral loss for incumbent parties, our analysis suggests that the persisting disenfranchisement of expatriates mainly results from the perceived cost of including them for the pursuit of nationalists' primary aim of acquiring further territorial autonomy. In Scotland, their inclusion was perceived as detrimental to a movement eager to tame down its ethnic undertones and stressing instead its progressive roots. By contrast in Flanders, it was apprehended through the lens of the linguistic conflict that has dominated Belgian politics for the past 50 years and suspiciously regarded as the Trojan horse of Francophone voters casting a ballot in Flemish elections.

\section{Conclusion}

This article started from the observation that the vast and ever-growing scholarship on external voting has neglected the level of elections in which noncitizens may participate from abroad, thereby perpetuating a statist perspective that it aimed to transcend in the first place. While the enfranchisement of regional expatriates remains less widespread than in national elections, our analysis revealed the broad range of electoral arrangements that can be found both within and across states, thereby calling for further empirical research into the topic.

It contributed to the overall aims of the Special Issue in at least two ways. First, it showed how political parties competing for office in a specific portion of the state territory contribute to shape the content of diaspora policy by selectively appealing to former residents according to their institutional capacity, electoral interests and regional autonomy aims. Second, it problematised the widely taken for granted identification of the diaspora with the nation-state. Diasporas not only are ideologically divided but also territorially tainted and may therefore primarily identify with and direct their claims to their region of origin. Notwithstanding the functionalist expectations of modernisation theory, territorial cleavages keep moulding the politics of virtually all nation-states and can be replicated in a transnational space where state and regional actors compete for the allegiance and resources of the same people. State-wide parties and governments are not the only 
actors involved in the making of diaspora communities, that may also be targeted by sub- state actors pursuing a distinct agenda and diverging interests. However, the struggle for the constitution of the diaspora is essentially asymmetric, as regional governments enjoy significantly less legislative and infrastructural power than states do to claim and reach out to their own populations abroad. Our Scottish and Flemish case studies illustrate this enduring asymmetry, even when regional actors enjoy considerable means of self-government in the homeland and strong identification among the population.

The article made a decisive move towards uncovering the 'micro-foundations' under- lying the making of regional diasporas nested within state diasporas, thereby opening a new research agenda. In order to fully grasp why regional expatriates are enfranchised in some regions but not in others, future research could build on our mapping exercise by either comparing regions within the same state in a most similar different outcome design, or regions in different countries in a most different similar outcome design (Lijphart 1971). Last but not least, the article exclusively focused on policy outputs and the institutional means through which regional diasporas can be politically constituted through voting beyond territory. Whether and under what conditions having the right to vote from abroad translates into actual participation and collective mobilisation of a selfidentified regional diaspora remains another crucial task for future research. 


\section{NOTES}

1. The data can be consulted online on the GLOBALCIT website at www.eudo-citizenship.e, chiefly the 2015 database on Conditions to Electoral Rights.

2. That is, the level which received the highest score in a given country in the 'Regional Auth- ority Index' by Hooghe et al. (2016).

3. The maps were generated with the software $\mathrm{R}$ through a 'home-made' programme. For the sake of clarity, remote island territories do not show on the maps (e.g. Azores, Guam). They were nonetheless coded and included in the appendix (see Supplemental data).

4. See Dunn v. Blumstein, 405 U.S. 330 (1972).

5. In both the Aland Islands and Trentino-Alto Adige, the durational residence requirement initially applying to Finnish and Italian citizens, respectively, was subsequently extended to citizens of other EU Member States in local elections, in the application of EU legislation on the matter.

6. Flanders may partly qualify as a case of 'interregional enfranchisement', as explained in the second part of this essay.

7. El Mundo, 'El PP pide que puedan votar en Euskadi los amenazados por ETA que se fueron', February 17, 2011.

8. La Vanguardia, 'El Gobierno vasco rechaza el voto en Euskadi de los 'exiliados' por ETA', April $16,2014$.

9. Following a 2013 reform of the German electoral law, citizens abroad no longer have to document past residence in Germany, as long as they can prove that they are personally acquainted with and directly affected by German politics.

10. While Italians abroad must return to their constituency of past residence to cast a ballot there on election day in all regions but Trentino-Alto Adige, most regional governments offer subsidy to travel back home on election day, with important variations. For example, Sicily only covers the cost of highway and regional trains, while Tuscany provides a reimbursement up to EUR200.

11. Authors' translation, Chambre, Annales, 28 novembre 2001, p. 57.

12. Authors' translation, Marc Hendrickx, Geef Vlamingen in buitenland ook stemrecht bij Vlaamse verkiezingen, 15 October 2015.

13. Authors' translation, Vlaamse Regering, Beslissingen van de Vlaamse Regering, 5 June 2015.

14. N-VA, Voting for Flanders: Also from abroad, 25 August 2016.

15. Commonwealth citizens with permanent Leave to Remain in the UK have the right to vote and stand as candidate in all types of elections in the UK. The issue of their enfranchisement in Scottish devolved elections was widely perceived as self-evident and hardly questioned among Scottish political elites prior to devolution.

16. House of Common Hansard Debates. June 17, 1997, vol. 295 cc247-79.

17. House of Common Hansard Debates. June 17, 1997, vol. 295 cc247-79.

18. House of Common Hansard Debates. June 17, 1997, vol. 295 cc247-79. 


\section{REFERENCES}

Achermann, A., C. Achermann, G. D’Amato, M. Kamm, B. Von Rütte, and N. Wichmann. 2015. Report on Citizenship Law: Switzerland. San Domenico di Fiesole: EUDO-CITIZENSHIP Observatory at the European University Institute

Arrighi, J. Th. 2012. "Those Who Came and Those Who Left: The Territorial Politics of Migration in Scotland and Catalonia." PhD diss., San Domenico di Fiesole: European University Institute.

Arrighi, J.-Th., and R. Bauböck. 2017. “A Multilevel Puzzle: Migrants' Voting Rights in National and Local Elections." European Journal of Political Research 56 (3): 619-639.

Blatter, J., and M. Haverland. 2012. Designing Case Studies: Explanatory Approaches in Small-N Research. London: Palgrave Macmillan.

Brand, L. A. 2014. "Arab Uprisings and the Changing Frontiers of Transnational Citizenship: Voting from Abroad in Political Transitions." Political Geography 41: 54-63.

Butler, K., N. Canefe, R. Cohen, W. A. Douglas, M. S. Laguerre, W. Safran, and G. Totoricagüena. 2007. Opportunity Structures in Diaspora Relations: Comparisons in Contemporary Multilevel Politics of Diaspora and Transnational Identity. Reno: Center for Basque Studies Press.

Collyer, M., and Z. Vathi. 2007. "Patterns of Extraterritorial Voting." Development Research Centre on Migration, Globalisation and Poverty Working Paper 22.

Délano Alonso, A., and H. Mylonas. 2017. "The Microfoundations of Diaspora Politics: Unpacking the State and Disaggregating the Diaspora." Journal of Ethnic and Migration Studies. Advance online publication. doi:10.1080/1369183X.2017.1409160.

Elazar, D. J. 1985. "Federalism and Consociational Regimes." Publius: The Journal of Federalism 15 (2): 17-34.

Gamlen, A., M. E. Cummings, and P. M. Vaaler. 2017. "Explaining the Rise of Diaspora Institutions." Journal of Ethnic and Migration Studies. Advance online publication. doi:10. 1080/1369183X.2017.1409163.

Grosso, E. 2012. "Regional Electoral Legislation in Italy: A Short Essay on the Rise and Fall of the Myth of Territorial Differentiation." Perspectives on Federalism 4 (1).

Hepburn, E., and R. Zapata-Barrero. 2014. The Politics of Immigration in Multilevel States: Governance and Political Parties. Basingstoke: Springer.

Hooghe, L., G. Marks, A. H. Schakel, S. C. Osterkatz, S. Niedzwiecki, and S. Shair-Rosenfield. 2016. Measuring Regional Authority: A Postfunctionalist Theory of Governance. Vol. 1. Oxford: Oxford University Press. 
Hutcheson, D. S., and J. T. Arrighi. 2015. ““Keeping Pandora's (Ballot) Box Half-shut”: A Comparative Inquiry into the Institutional Limits of External Voting in EU Member States." Democratization 22 (5): 884-905.

Jackson, V. 2001. "Citizenship and Federalism." In Citizenship Today: Global Perspectives and Practices, edited by A. Aleinikoff, and D. Klusmeyer, 127-143. Washington, DC: Brookings Institution Press.

Jeffery, C., and D. Wincott. 2010. "Beyond Methodological Nationalism: The Challenge of Territorial Politics." In New Directions in Political Science, edited by C. Hay, 167-188. Basingstoke: Palgrace Macmillan.

Jones-Correa, M., and D. Wong. 2015. Report on Electoral Rights: USA. EUDO-CITIZENSHIP Observatory at the European University Institute.

Keating, M. 1998. The New Regionalism in Western Europe: Territorial Restructuring and Political Change. Aldershot: Edward Elgar.

Keating, M. 2013. Rescaling the European State: The Making of Territory and the Rise of the Meso. Oxford: Oxford University Press.

Kiely, R., F. Bechhofer, and D. McCrone. 2005. "Birth, Blood and Belonging: Identity Claims in Post-devolution Scotland.” The Sociological Review 53 (1): 150-171.

Kousser, J. M. 1999. Colorblind Injustice: Minority Voting Rights and the Undoing of the Second Reconstruction. Chapel Hill: University of North Carolina Press.

Kriesi, H. 1995. "The Political Opportunity Structure of New Social Movements: Its Impact on Their Mobilization." In The Politics of Social Protest: Comparative Perspectives on States and Social Movements, edited by J. Jenkins, 167-198. Minneapolis: University of Minnesota Press.

Lafleur, J.-M. 2013a. Transnational Politics and the State. The External Voting Rights of Diasporas. New York: Routledge.

Lafleur, J.-M. 2013b. "La participation politique transnationale des Belges expatriés: un cas d'exportation des divisions ethniques?" Revue Européenne des Migrations Internationales 29 (2): $115-135$.

Lafleur, J.-M. 2015. "The Enfranchisement of Citizens Abroad: Variations and Explanations." Democratization 22 (5): 840-860.

Lafleur, J.-M., and L. Calderon Chelius. 2011. “Assessing Emigrant Participation in Home Country Elections: The Case of Mexico's 2006 Presidential Election." International Migration 49 (3): 99 124. 
Lijphart, A. 1971. "Comparative Politics and the Comparative Method." American Political Science Review 65 (3): 682-693.

Mahoney, J., and G. Goertz. 2004. "The Possibility Principle: Choosing Negative Cases in Comparative Research.” American Political Science Review 98 (04): 653-669.

McCrone, D. 2002. Understanding Scotland: The Sociology of a Nation. London: Routledge. Mitchell, J. 2006. "Evolution and Devolution: Citizenship, Institutions, and Public Policy." Publius: The Journal of Federalism 36 (1): 153-168. Murray, F. 2012. The European Union and Member State Territories: A New Legal Framework under

the EU Treaties. The Hague: Springer Science \& Business Media. Norman, W. 2006. Negotiating Nationalism: Nation-building, Federalism, and Secession in the Multinational State. Oxford: Oxford University Press.

Painter, J. 2002. "Multi-level Citizenship, Identity and Regions in Contemporary Europe." In Transnational Democracy: Political Spaces and Border Crossings, edited by J. Anderson, 93-110. London: Routledge.

Pauwels, T. 2011. "Explaining the Strange Decline of the Populist Radical Right Vlaams Belang in Belgium: The Impact of Permanent Opposition." Acta Politica 46 (1): 60-82.

Pedroza, L. 2015. Report on Access to Electoral Rights: Mexico. EUDO-CITIZENSHIP Observatory at the European University Institute.

Piccoli, L. 2016. "Left Out by the State, Taken in by the Region? Explaining the Regional Variation of Healthcare Rights for Undocumented Migrants." NCCR on the move Working Paper Series, Neuchâtel: Université de Neuchâtel.

Rhodes, S., and A. Harutyunyan. 2010. "Extending Citizenship to Emigrants: Democratic Contestation and a new Global Norm." International Political Science Review 31 (4): 470-493.

Schakel, A. H., and C. Jeffery. 2013. "Are Regional Elections Really 'Second-Order' Elections?" Regional Studies 47 (3): 323-341.

Scottish Government, Scotland's International Framework. 2015. Department of European and External Affairs.

Scottish Government Social Research. 2009a. Scotland's Diaspora and Overseas-Born Population.

Scottish Government Social Research. 2009b. Engaging the Scottish Diaspora: Rationale, Benefits and Challenges. Department of European and External Affairs.

Stepan, A. C. 1999. "Federalism and Democracy: Beyond the U.S. Model.” Journal of Democracy 10 (4): 19-34. 
Studer, B., G. Arlettaz, and R. Argast Kury. 2013. Le droit d'être Suisse: acquisition, perte et retrait de la nationalité de 1848 à nos jours. Lausanne: Antipodes. Tilly, C. 1997. "A Primer on Citizenship." Theory and Society 26: 599-603.

Turcu, A., and R. Urbatsch. 2015. "Diffusion of Diaspora Enfranchisement Norms: A Multinational Study." Comparative Political Studies 48 (4): 407-437. 